\title{
ANALISIS INVESTASI DAN PENENTUAN PORTOFOLIO SAHAM OPTIMAL DENGAN METODE INDEKS TUNGGAL (STUDI EMPIRIS PADA IDX 30 YANG TERDAFTAR DI DI BURSA EFEK INDONESIA PERIODE AGUSTUS 2017-JANUARI 2018)
}

\author{
Sri Mulyati ${ }^{1}$, Ania Murni ${ }^{2}$ \\ srimulyati@unimal.ac.id \\ ${ }^{1,2}$ Prodi Akuntansi Fakultas Ekonomi dan Bisnis Universitas Malikussaleh Lhokseumawe
}

\begin{abstract}
This study aims to analyze investment and determine the optimal stock portofolio with single indexs method. The data used in this study is secondary data obtained from 30 idx 30 companies accessed on www.idx.co.id, www yahoofinance.co.id, adnd www.bi.go.id, and obtained through documentation and library research study techniques. This study uses a descriptive research method with a quantitative approache. The results of this study indicate that there are seven optimal companies because the ERB(expected return to beta) values are higher than the CI value of LPKR, PGAS, PTPP, SMGR, SRIL, UNTR AND SMGR.
\end{abstract}

Keywords :Optimal Portofolio, single Indeks Method

\section{PENDAHULUAN}

Perkembangan ekonomi secara keseluruhan dapat dilihat dari perkembangan pasar modal dan industri sekuritas pada suatu Negara.Pasar modal memiliki peranan penting sebagai salah satu tempat investasi keuangan dalam dunia perekonomian. Selain itu pasar modal juga merupakan tempat untuk mempertemukan pihak yang kelebihan dana atau lender dan pihik yang membutuhkan dana atau borrower. Dengan bantuan pasar modal pihak lender dan borrower dapat melakukan kegiatan bisnis dengan efesien dan efektif.

Produk-produk investasi yang ditawarkan kepada investor dipasar modal adalah reksadana, saham, saham preferen, obligasi, waran, dan right issue, dan yang ingin peneliti teliti disini adalah tentang saham,dimana para investor menanan saham-saham nya pada perusahaan perusahaan tertentu, dan disisni peneulis ingin meneliti tentang bagaimana supaya investor bisa meminimalkan risiko dalam berinvestasi dengan cara menentukan portofolio yang optimal.

Semakin banyaknya perusahaan yang menjadi emiten di pasar modal akan menimbulkan berbagai kombinasi saham yang bisa di pilih oleh investor dalam berinvestasi di pasar modal portofolio. Berdasarkan kenyataan bahwa pada umumnya investor tidak menginvestasikan seluruh dananya pada satu jenis saham tapi mereka melakukan diversifikasi saham yang bertujuan untuk mengurangi risiko yang ditanggung akibat dana yang diinvestasikan.

Untuk mendapatkan keuntungan yang semaksimal mungkin maka analisis portofolio merupakan salah satu alat yang tepat untuk memperkecil risiko yang diterima dengan tujuan memaksimalkan profit dengan tingkat risiko yang sama diantara saham yang ada. Hasil dari analisis ini akan menentukan ketepatan dalam pengambilan keputusan investasi yang akan diambil oleh investor Firdausy (2015)

Salah satu teknis analisa portofolio optimal yang dilakukan oleh Elton dan Gruber (1995) adalah menggunakan indeks tunggal. Analisis atas sekuritas dilakukan dengan membandingkan excess return to beta (ERB) dengan cut off-off-rate-nya (Ci) dari masing-masing saham. Saham yang memiliki ERB lebih besar dari Ci dijadikan kandidat portofolio, sedang sebaliknya yaitu $\mathrm{Ci}$ lebih besar dari ERB tidak diikutkan dalam portofolio. 
Pertimbangan pemilihan konstituen indeks IDX 30 adalah karena terdapat indeks 30 saham perusahaan yang memiliki likuiditas tinggi dan kapitalisasi yang besar di pasar modal Indonesia yaitu indeks IDX 30 saham yang banyak diperdagangkan dan memiliki kapitalisasi pasar yang besar serta likuiditas yang tinggi. Saham-saham perusahaan tersebut adalah saham-saham yang baik untuk investasi saham, karena harganay stabil, tidak mudah dimanipulasi dan memiliki risiko yang lebih rendah dibandingkan perusahaan yang kurang likuid dan sahamnya hanya seikit yang diperdagangkan di pasar modal. Selain itu juga factor kuantitaif yang terkait dengan nilai, ferkuensi, dan hari transaksi serta kapitalisasi pasar. Selain factor-faktor yang bersifat kuantitatif tersebut, Bursa Efek Indonesia juga mempertimbangkan informasi kelangsungan usaha, lapran keuangan, dan pertimbangan lainnya, komstituen IDX 30 akan dikaji ulang setiap enam bulan sekali yaitu setiap akhir bulan Januari dan Juli hasilnya akan diumumkan pada awal bulan berikutnya.berdasarkan uraian diatas penulis tertarik untuk melakukan suatu penelitian yang berjudul : ANALISIS INVESTASI DAN PENENTUAN PORTOFOLIO SAHAM OPTIMAL DENGAN METODE INDEKS TUNGGAL (Studi Empiris Pada IDX 30 Yang Terdaftar Di Bursa Efek Indonesia Periode Agustus 207-januari 2018).

\section{Pengertian Investasi}

\section{TINJAUAN PUSTAKA}

Invetasi adalah penanaman modal pada satu atau lebih aktiva yang dimiliki dan biasanya berjangka waktu lama dengan harapan mendapatkan keuntungan dimasa-masa yang akan datang. Keputusan penanaman modal tersebut dapat dilakukan oleh individu atau suatu entitas yang mempunyai kelebihan dana Sunariyah (2011: 4)

Investasi merupakan suatu kegiatan untuk mengeluarkan nilai saat ini untuk mengharapkan keuntungan pada waktu yang akan datang. Pada dasarnya investasi dilakukan untuk mencari keuntungan tertentu.Salah satu alasan seseorang untuk melakukan investasi adalah tidak menentunya lingkungan perekonomian sehingga memungkinkan suatu saat penghasilan lebih kecil dari pengeluaran.
Ada dua bentuk investasi yaitu Investasi pada real asset yaitu investasi yang menanamkan modalnya dengan cara membeli asset produktif seperti tanah dan bangunan sedangkan investasi financial asset adalah investasi yang dilakukan pada pasar uang dan pasar modal Provita (2013)

\section{RETURN}

Return merupakan tujuan para investor dalam berinvestasi.untuk memaksimalkan return yang diharapkan dengan tingkat resiko tertentu, biasanya para investor menyiasati dengan portofolio saham dan salah satu cara ntuk mengurangi risiko investasi saham bisa dilakukan dengan melakukan difersivikasi kepemilikan saham, yaitu dengan mengkombinasikan berbagai saham dalam investasinya atau dengan membentuk portofolio. Karena pada dasarnya investor sangat menyukai investasi yang menghasilkan pengembalian yang tinggi, akan tetapi tidak begitu menyukai akan adanya risiko. Firdausy (2015)

return adalah pendapatan yang dinyatakan dalam persentase dari modal awal investasi. Pendapatan investasi dalam saham ini merupakan keuntungan yang diperoleh dari jual beli saham, dimana jika untung disebut capital gain dan jika rugi disebut capital loss( Samsul: 315)

\section{RISIKO}

Risiko merupakan besarnya penyimpangan antara tingkat pengembalian yang diharapkan (expected return) dengan tingkat pengembalian yang diperoleh, semakin besar penyimpangan berarti semakin besar resiko nya Halim (2005:42)

Untuk mengukur risiko secara umum, risiko dibagi dalam dua jenis, yaitu: systematic risk dan unsystematic risk. Apabila risiko sistematis muncul dan terjadi maka semua jenis saham akan terkena dampaknya, sehingga investasi pada satu jenis saham ataupun lebih tidak dapat mengurangi kerugian .contoh risiko sistematis adalah tingkat inflasi, tingkat bunga, kebijakan fiskal, pertumbuhan ekonomi, kurs, valuta asing, dan siklus ekonomi. Sedangkan unsystematic risk atau risiko spesifik hanya berdampak terhadap suatu saham sektor tertentu, karena risiko tersebut dapat diatasi dengan cara melakukan diversifikasi produk Samsul(2015:309) 


\section{Portofolio}

Portofolio adalah gabungan dari berbagai instrument investasi baik baik yang berbentuk tanpa disengaja atau memang diputuskan melalui perencanaan yang didukung dengan perhitungan dan pertimbangan rasional untuk memaksimumkan risiko investasi. Sulisistiyowati (2017)

Portofolio optimal merupakan portofolio yang dipilih investor dari sekian banyak pilihan yang ada pada portofolio efisien, sedangkan portofolio efisien itu sendiri adalah portofolio yang menyediakan return maksimal bagi investor dengan tingkat risiko tertentu. Choiriyah (2016).

Portofolio optimal merupakan portofolio yang dipilih investor dari sekian banyak pilihan yang ada pada portofolio efisien, sedangkan portofolio efisien itu sendiri adalah portofolio yang menyediakan return maksimal bagi investor dengan tingkat risiko tertentu. Choiriyah (2016).

Portofolio efisien merupakan portofolio yang baik namun bukan yang terbaik. Investor mengharapkan return dan risiko terbaik, maka perlu dibentuk portofolio optimal. "Portofolio optimal merupakan bagian dari portofolio-portofolio efisien.Suatu portofolio optimal jugasekaligus merupakan suatu portofolio efisien, tetapi suatu portofolio efisien belum tentu portofolio optimal". Portofolio optimal merupakan portofolio dengan kombinasi return ekpektasian dan risiko terbaik

\section{Metode Indeks Tunggal}

Single index model atau model indeks tunggal adalah sebuah teknik untuk mengukur return dan risiko sebuah saham atau portofolio. Model tersebut mengasumsikan bahwa pergerakan return saham hanya berhubungan dengan pergerakan pasar. Sensitifitas pergerakan return saham terhadap pergerakan return pasar diukur dengan Beta. Berikut ini adalah rumus yang perlu digunakan dalam mencari portofolio model Indeks tunggal dengan rumus sebagai berikut menurut Jugiyanto (2014) dalam Graha (2016).

a. Menghitung nilai return individu dan risiko saham individu, return saham individu dapat di hitung dengan rumus:

$\operatorname{Rt}(\mathrm{i}) \frac{p t-p t-1}{p t-1}$

Keterangan:
$\operatorname{Rt}(\mathrm{i})=$ return saham $\mathrm{i}$
$\mathrm{Pt}=$ closing price saham i bulan ke $\mathrm{t}$

Pt-1 = closing price

Saham I bulan

Ke $t 1$

b. Nilai return ekspektasi saham dapat di hitung dengan rumus:

$\mathrm{E}(\mathrm{Ri})=\frac{\sum R t(i)}{n}$

Keterangan:

$\mathrm{E}(\mathrm{Ri})=$ Expected Return

Rt(i) = Return saham $\mathrm{i}$

$\mathrm{N} \quad=$ Jumlah periode

c. Menghitung alpha dan beta sekuritas

$\beta=\frac{\sigma i m}{\sigma^{2} m}$

keterangan:

$\beta=$ Beta Sekuritas

бim = kovarian

$\sigma^{2} \mathrm{~m}=$ Standar Deviasi

Sedangkan alpha dapat dihitung dengan rumus:

$\alpha \mathrm{i}=\sigma \mathrm{i}^{2}-\left(\beta \mathrm{i}^{2} \cdot \sigma^{2} \mathrm{~m}\right)$

keterangan:

$\sigma \mathrm{ei}^{2}=$ Varian error residual risiko tidak sistematis saham

d. Menghitung excess return to beta

$\mathrm{ERBi}=\frac{E(R i)-R B R}{\beta i}$

Keterangan:

$\mathrm{ERBi}=$ excess ruturn to

berta

RBR = Return bebas

risiko

$\beta \mathrm{i}=$ beta sekuritas

ke-i

e. Menghitung cut off point 
PT. Bursa Efek Indonesia, pada tanggal 23 april 2012 meluncurkan indeks harga saham baru dengan nama indeks IDX 30. Indeks IDX 30 merupakan Indeks yang terdiri dari 30 saham yang kostituen nya dipilih dari konstituen indeks LQ 45. Dasar pertimbangan pertimbangan pemiihan konstituen Indeks IDX 30 adalah faktor kuantitatif yang terkait dengan nilai, frekuensi, dan hari transaksi serta kapitalisasi pasar. Selain factor - factor yang bersifat kuantitatif tersebut, Bursa Efek Indonesia juga mempertimbangkan informasi kelangsungan usaha, laporan keungan, dan pertimbangan lainnya, konstituen Indeks IDX 30 akan dikaji ulang setiap enam bulan sekaliyaitu setiap akhir bulan januari dan juli dan hasilnya akan di umum kan pada awal bulan berikut nya.

\section{Kerangka Konseptual}

Berdasarkan hal tersebut diatas maka peneliiti menarik kesimpulan dalam kesimpulan sebagai berikut:

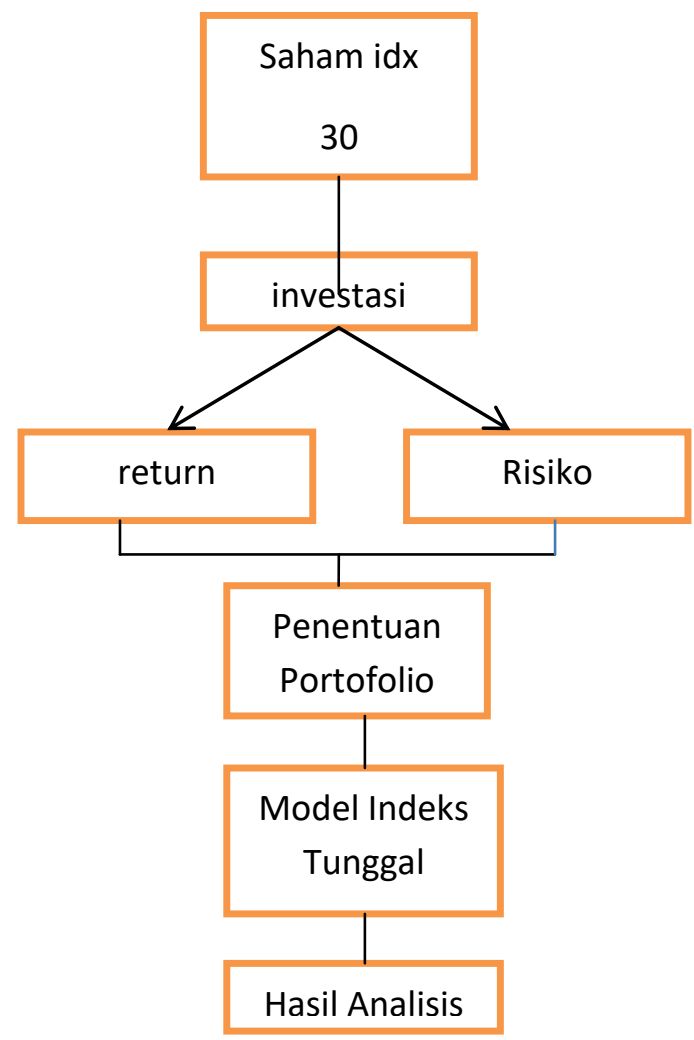

Gambar .1 Kerangka Konseptual Penelitian Terdahulu
Adapun penelitian terdahulu dalam penelitian ini adalah:

1. Wibowo dkk. (2014) Meneliti Tentang "Penerapan Model Indeks Tunggal Untuk Menetapkan Komposisi Portofolio Optimal (Studi Pada Saham-Saham Lq 45 Yang Listing Di Bursa Efek Indonesia (Bei) Tahun 2010-2012)". Sampel yang digunakan sebanyak 22 perusahaan.Hasil dari penelitian tersebut adalah dari 22 sampel saham diperoleh 14 saham yang membentuk komposisi portofolio optimal. Saham-saham tersebut adalah GGRM, KLBF, JSMR, ASII, SMGR, INTP, LPKR, BBCA, BBNI, INDF, PGAS, BMRI, BBRI dan BDMN, dengan proporsi dana masing besarnya 3,95\%, 16,35\%, $17,13 \%, 15,24 \%, 7,62 \%, 4,82 \%, 3,30 \%$, $10,18 \%, 5,50 \%, 4,15 \%, 1,40 \%, 7,68 \%$, $2,27 \%$ dan $0,40 \%$. Proporsi dana terbesar dimiliki oleh JSMR yaitu $17,13 \%$ sedangkan proporsi dana terendah dimiliki oleh BDMN yaitu $0,40 \%$. Dari portofolio yang terbentuk menghasilkan perhitungan return portofolio sebesar 0,0332245 atau $3,32 \%$ dan risiko portofolio sebesar 0,002187441 atau $0,22 \%$. Dari hasil perhitungan tersebut menunjukkan bahwa risiko Analisis Portofolio Optimal Model indeks tunggal portofolio lebih kecil dibandingkan dengan risiko saham sebelum portofolio.Hal ini menunjukkan bahwa dengan membentuk portofolio optimal dapat menurunkan besarnya risiko.

2. Natalia dkk. (2014)

Meneliti Tentang "Penentuan Portofolio Saham Yang Optimal Dengan Model Markowitz Sebagai Dasar Penetapan Investasi Saham (Studi Pada Perusahaan Food And Beverage Yang Terdaftar Di Bursa Efek Indonesia Tahun 2012)". Sampel yang digunakan sebanyak 9 sampel perusahaan.Hasil penelitian tersebut adalah setelah dianalisis dengan mengunakan Model Markowitz ternyata kesembilan saham tersebut tergolong dalam portofolio optimal. Saham-saham tersebut adalah: PT. Tiga Pilar Sejahtera Food Tbk (AISA), dengan proporsi sebesar 2,86\%, PT. Delta Djakarta Tbk (DLTA), dengan proporsi sebesar 16,20\%, PT IndoFood CBP Sukses Makmur (ICBP), dengan proporsi sebesar 8,34\%, PT. IndoFood Sukses Makmur, Tbk (INDF), dengan proporsi sebesar 14,21\%, 
PT Multi Bintang Indonesia Tbk (MLBI) dengan proporsi sebesar 6,86\%, PT. Mayora Indah Tbk (MYOR) dengan proporsi sebesar $8,10 \%$, PT Nippon Indosari Corpindo (ROTI) dengan proporsi sebesar 5,72\%, PT. Sekar Laut Tbk (SKLT) dengan proporsi sebesar 31,33\%, PT. Ultra Jaya Industri, Tbk (ULTJ) dengan proporsi sebesar 6,39\%.

\section{Panjaya (2014)}

Meneliti Tentang "Optimalisasi Portofolio Dengan Kombinasi Indeks Kompas 100 Menggunakan Analisis Single Index Model". Sampel yang digunakan sebanyak 47 perusahaan.Data keuangan yang digunakan dalam penelitian ini adalah data keuangan dari 1 Agustus 2012 sampai dengan 31 Juli 2013. Dari hasil penelitian tersebut diperoleh 7 saham yang masuk dalam kategori portofolio optimal yaitu, PT Kalbe Farma Tbk, PT Telekmonikasi Indonesia tbk, PT Elnusa Tbk, PT Perusahaan Gas Negara Persero Tbk, PT Bank Central Asia Tbk, PT Ciputra Development Tbk, PT Global Mediacom Tbk.

\section{Arifin (2015)}

Meneliti Tentang "Analisis Portofolio Optimal Dengan Model Indeks Tunggal Sebagai Dasar Penentuan Keputusan Investasi Pada Saham Sektor Perbankan di Bursa Efek Indonesia" sampel yang digunakan dalam penelitian sebanyak 6 perusahaan.Data yang digunakan adalah datakeuangan dari tahun 2009-2013. Hasil dari penelitian tersebut diperoleh 4 saham yang masuk dalam kategori portofolio optimal yaitu, PT Bank Negara Indonesia, PT Bank Rakyat Indonesia, PT Bank Tabungan Negara, PT Bank Danamon Indonesia. Dari keempat saham tersebut diperoleh kombinasi portofolio optimal 50\%:50\%， 60\%:40\%， 70\%:30\%. Titik efisien terdapat pada titik portofolio 1 dan portofolio 3.

\section{METODE PENELITIAN}

\section{Lokasi Penelitian}

Penelitian ini dilakukan di Bursa Efek Indonesia dengan mencatat daftar sahamsaham yang masuk dalam Indeks IDX 30 periode Agustus 2017-Januari 2018.
Penelitian ini merupakan penelitian deskriptif, yaitu penelitian yang diarahkan untuk memberikan gejala-gejala,fakta atau kejadian secara sistematis dan akurat mengenai sifat-sifat populasi atau daerah tertentu Zuriah dalam Dahlan dkk (2013) pendekatan yang digunakan dalam penelitian ini adalah pendekatan kuantitatif, karena data utama yang digunakan dalam penelitian ini adalah data yang bebentuk angka atau data kuantitatif yang diangkakan Sugiyono dalam dahlan dkk (2013)Adapun perusahan-perusahan tersebut adalah

Tabel .1 daftar perusahan yang terdaftar di IDX 30 periode Agustus 2017-Januari 2018

\begin{tabular}{|l|l|l|}
\hline No & kode & \multicolumn{2}{|c|}{ Nama Saham } \\
\hline 1 & ADHI & Adhi Karya (persero) Tbk \\
\hline 2 & ADRO & Adaro Energy Tbk \\
\hline 3 & ANTM & AKR CorporindonTbk \\
\hline 4 & ASII & Astra Internasional Tbk \\
\hline 5 & BBCA & Bank Central Asia Tbk \\
\hline 6 & BBNI & $\begin{array}{l}\text { Bank Negara Indonesia } \\
\text { (persero)Tbk }\end{array}$ \\
\hline 7 & BBRI & $\begin{array}{l}\text { Bank Rakyat Indonesia } \\
\text { (Persero) Tbk }\end{array}$ \\
\hline 8 & BMRI & Bnk Mandiri (Persero) Tbk \\
\hline 9 & BSDE & Bumi Serpong Damai Tbk \\
\hline 10 & GGRM & Gudang Garam Tbk \\
\hline 11 & HMSP & H.M.Sampoerna Tbk \\
\hline 12 & ICBP & $\begin{array}{l}\text { Indofood CBP SUKSER } \\
\text { Makmur Tbk }\end{array}$ \\
\hline 13 & INDF & $\begin{array}{l}\text { Indofood Sukser Makmur } \\
\text { Tbk }\end{array}$ \\
\hline 14 & INTP & $\begin{array}{l}\text { Indocement } \\
\text { Prakarsa Tbk }\end{array}$ \\
\hline 15 & JSMR & Jasa Marga (Persero) Tbk \\
\hline 16 & KLBF & Kalbe Farma Tbk \\
\hline 17 & LPKR & Lippo Karawaci Tbk \\
\hline 18 & LPPF & $\begin{array}{l}\text { Matahari Depertment Store } \\
\text { Tbk }\end{array}$ \\
\hline 19 & MNCN & Media Nusantara Citra Tbk \\
\hline 20 & PGAS & $\begin{array}{l}\text { Perusahaan Gas Negara } \\
\text { (Persero) Tbk }\end{array}$ \\
\hline 21 & PPRO & Pp Properti Tbk \\
\hline 22 & PTPP & Pp(persero) Tbk \\
\hline 23 & PWON & $\begin{array}{l}\text { Semen Indonesia (Persero) } \\
\text { Tbk }\end{array}$ \\
\hline 24 & SMGR & Summarecon Agung Tbk \\
\hline 25 & SRIL & Sri Rejeki Isman Tbk \\
\hline 26 & SSMS & $\begin{array}{l}\text { Sawit Sumbermas Sarana } \\
\text { Tbk }\end{array}$ \\
\hline 27 & TLKM & Telekomunikasi Indonesia \\
\hline & & \multicolumn{2}{|c|}{ Sugal } \\
\hline 19
\end{tabular}




\begin{tabular}{|l|l|l|}
\hline & & (Persero) Tbk \\
\hline 28 & UNTR & United Tractors Tbk \\
\hline 29 & UNVR & Unilever Indonesia Tbk \\
\hline 30 & WSKT & Waskita Karya (Persero) \\
\hline
\end{tabular}

\section{Populasi dan Sampel}

Populasi yang digunakan dalam penelitian ini adalah saham-saham perusahaan yang termasuk dalam anggota Indeks IDX 30 periode Agustus 2017-Januari 2018 yaitu sebanyak 30 perusahaan. Sedangkan sampel yang peneliti gunakan dalam penelitian ini adalah sensus sampling atau sampel jenuh dimana seluruh populasi dijadikan sampel Sugiyono (2016:85).

\section{Jenis dan Sumber Data}

Penelitian ini menggunakan data sekunder .Data sekunder merupakan data yang di peroleh peneliti secara tidak langsung atau melalui perantara. Data-data yang diperlukan dalam penelitian ini adalah sebagai berikut:

1. Data harga saham, data harga saham yang akan diteliti adalah harga saham penutupan (closing price) pada setiap akhir bulan.

2. Data Indeks harga saham gabungan (IHSG), data IHSG di ambil dari penutupan bulanan indeks selama periode Agustus 2017- Januari 2018, data IHSG mewakili data pasar, diperlukan untuk menghitung tingkat return $(\mathrm{Rm})$ dari resiko pasar

3. Data BI rate merupakan proxy return aktiva bebas resiko (Risk free rate of return).

Sedangkan sumber data penelitian ini diperoleh dari www.idx.co.id, yahoo finance.co.id dan www.Bi.go.id. serta berbagai literatur untuk penggunaan hasil penelitian dan konsep-kosep yang dibutuhkan.

\section{Teknik Pengumpulan Data}

Adapun metode pengumpulan data yang digunakan dalam penelitian ini adalah:

\section{Teknik dokumentasi}

Teknik dokumentasi yaitu teknik pengumpulan data yang dilakukan dengan mencari data mengenai hal-hal atau variabel yang diteliti. Data yang digunakan dalam penelitian yaitu dengan mencatat dan mengkopi data yang tercantum dalam PT. Bursa Efek Indonesia melalui laman web www.idx.co.id, yahoo finance.co.id dan www.Bi.go.id. serta berbagai literatur untuk penggunaan hasil penelitian dan konsep-kosep yang dibutuhkan.

2. Studi kepustakaan

Studi pustaka merupakan segala usaha yang dilakukan oleh peneliti untuk mendapatkan informasi yang relevan dengan topik atau masalah yang akan diteliti, kerangan ilmiah, peraturanperaturan dan sumber-sumber tertulis baik tercetak maupun elektronik.

\section{Definisi Operasionalisasi}

Berikut ini adalah definisi operasional. Beberapa hal yang berhubungan dengan portofolio optimal, yaitu:

1. Metode single indeks model (model indeks tunggal), didasarkan pada pengamatan bahwa harga suatu sekuritas berfluktuasi searah dengan indeks pasar. Apabila diamati kebanyakan saham cenderung mengalami kenaikan harga jika indeks harga saham naik dan sebaliknya saham mengalami penurunan harga jika Indeks harga saham juga turun. Indikator variabel model indeks tunggal adalah sebagai berikut

a. Return dan risiko saham

Return dan risiko saham dihitung sebagai komponen model indeks tunggal. Data yang digunakan adalah data penutupan harga saham bulanan pada periode Agustus 2017-Januari2018

b. Return dan risiko pasar Diasumsikan bahwa pergerakan saham seiring dengan pergerakan harga pasar. Data yang digunakan adalah data IHSG

c. Alpha dan Beta sekuritas Alpha digunakan untuk menghitung varianceerror, sedangkan beta adalah adalah risiko unik saham individual,

d. Kesalahan Residu dan Varian Residu 
Variance $\left(\sigma \mathrm{ei}^{2}\right)$ adalah varian dari residual error saham I yang juga merupakan dari risiko unit

2. Portofolio Optimal

Portofolio Optimal adalah kombinasi aset dari suatu portofolio yang memiliki karakteristik kenaikan tingkat harapan imbal hasil yang paling tinggi terhadap kombinasi-kombinasi yang dimungkinkan lainnya.

a. Excess return to beta

Excess return to beta (ERB) digunakan untuk mengukur return saham relative terhadap satu unit risiko yang tidak dapat di diversikasi yang diukur dengan beta. ERB menunjukkan hubungan antara return dan risiko yang merupakan factor penentu investasi

b. Titik pembatas (cutt off point)

Nilai $C i$ merupakan hasil bagi varian pasar dan return premium terhadap variance error saham dengan varian pasar dan sensivitas saham individual terhadap variance error saham

\section{Teknik Analisis Data}

Analisis data dilakukan dengan menggunkan model indeks tunggal untuk menentukan portofolio yang optimal. Sedangkan perhitungannya dilakukan denganmenggunakan program excel. Adapun langkah-langkah yang akan dilakukan adalah sebagai beriku:

1. Mendeskripsikan perkembangan harga saham,IHSG, dan Bi rate

2. Menghitung return dan risiko individu berdasarkan pendekatan model indeks tunggal

3. Menghitung Beta dan Alpha berdasarkan pendekatan Model Indeks Tunggal

4. Menghitung Varian Residu

5. Menghitung kovarian saham

6. Menentukan portofolio optimal dengan model indeks tunggal. Setelah return, varians.beta dan alpha masing-masing saham diketahui, langkah selanjutnya untuk menentukan portofolio optimal dengan menggunakan model ideks tunggal adalah dengan menghitung tingkat Excess Return to Beta (ERB) serta menentukan Cut Off Point (Ci) sebagai berikuut:

a. Menghitung Excess Return to Beta

b. Menentukan titik pembatas (cut off point)

7. Besarnya titik pembatas dapat ditentukan dengan langkah-langkah sebagai berikut:

1. Urutkan sekuritas-sekuritas berdasarkan nilai ERB terbesar ke nilai ERB terkecil. Sekuritassekuritas dengan nilai ERB tinggi merupkan kandidat yang akan dimasukkan kedalam portofolio optimal

2. Sebelum menghitung nilai $\mathrm{Ci}$ terlebih dahulu kita menghitung nilai $\mathrm{Ai}$ dan Bi untuk masingmasing sekritas ke-i

3. Menghitung nilai $\mathrm{Ci}$, dikarenakan kita sudah menghitung nila Ai dan Bi

4. sekuritas-sekuritas yang membentuk portofolio optimal adalah sekuritas-sekuritas yang mempunyai nilai ERB lebih besar atau sama dengan nilai ERB di titik cut off point. Sekuritas-sekuritas yang memiliki ERB lebih kecil dengan ERB di titik cut off point tidak di ikut sertakan dalam pembentukan potofolio optimal.

\section{HASIL PENELITIAN DAN PEMBAHASAN}

Analisis investasi portofolio optimal dengan model indeks tunggal pada kelompok saham IDX 30 berdasarkan penelitian yang dilakukan oleh peneliti maka terdapat tujuh perusahan yang masuk kedalam portofolio optimal dan perusahaan tersebut adalah LPKR, PGAS, PTPP,SMGR, SRIL,UNTR, dan UNVR. Dikatakan optimal dikarenakan nilai ERB nya lebih besar dibandingkan nilai $\mathrm{Ci}$ nya. Dalam berinvestasi kita tidak terlepas oleh risiko oleh sebab itu kita harus membentuk portofolio yaitu dengan cara diversifikasi saham dan hasil penelitian ini juga di dukung oleh Firdaausy (2015) dimana hasil penelitian Firdausy adalah berdasarkan hasil perhitungan yang telah diperoleh maka, hasil 
dari analisis investasi melalui penetapatan portofolio saham optimal pada saham 1Q 45 bursa efek Indonesia dengan menggunakan metode indeks tunggal sehingga diperoleh beberapa saham yang optimal, setelah menghitung return dan risk setiap saham sehingga menentukan titik pembatas yang dibandingkan dengan ERB (Excess Return to Beta).

Tabel .2ERB dan Ci

\begin{tabular}{|c|c|c|c|}
\hline $\mathrm{NO}$ & Emiten & ERB & CI \\
\hline 1 & LPKR & 1,93259 & 0,00004 \\
\hline 2 & PTPP & 0,00353 & 0,00046 \\
\hline 3 & SMGR & 0,00717 & 0,00158 \\
\hline 4 & PGAS & 0,01088 & 0,00136 \\
\hline 5 & UNVR & 0,00827 & $-0,00204$ \\
\hline 6 & SRIL & 0,10258 & $-0,00205$ \\
\hline 7 & UNTR & 0,04114 & $\mathbf{0 , 0 0 2 1 0}$ \\
\hline 8 & BMRI & $-0,03844$ & $-0,00177$ \\
\hline 9 & BSDE & $-0,00745$ & $-0,00183$ \\
\hline 10 & GGRM & $-0,03769$ & $-0,00181$ \\
\hline 11 & HMSP & $-0,02260$ & $-0,00170$ \\
\hline 12 & ICBP & $-0,04340$ & $-0,00264$ \\
\hline 13 & INDF & $-0,03777$ & $-0,00303$ \\
\hline 14 & INTP & $-0,01822$ & $-0,00242$ \\
\hline 15 & JSMR & $-0,06266$ & $-0,00194$ \\
\hline 16 & KLBF & $-0,06661$ & $-0,00195$ \\
\hline 17 & ADHI & $-0,03283$ & 0,00000 \\
\hline 18 & LPPF & $-0,05390$ & $-0,00207$ \\
\hline 19 & MNCN & $-0,00838$ & $-0,00120$ \\
\hline 20 & ADRO & $-0,01597$ & $-0,00165$ \\
\hline 21 & PPRO & $-0,05819$ & $-0,00237$ \\
\hline 22 & ANTM & $-0,02780$ & $-0,00144$ \\
\hline 23 & PWON & $-0,00239$ & $-0,00068$ \\
\hline 24 & ASII & $-0,04207$ & $-0,00215$ \\
\hline 25 & BBCA & $-0,03386$ & $-0,00205$ \\
\hline 26 & SSMS & $-0,05424$ & $-0,00141$ \\
\hline 27 & TLKM & $-0,07357$ & 0,00757 \\
\hline 28 & BBNI & $-0,02561$ & $-0,00208$ \\
\hline 29 & BBRI & $-0,03013$ & $-0,00213$ \\
\hline 30 & WSKT & $-0,05490$ & $-0,00205$ \\
\hline
\end{tabular}

Dari tabel diatas bisa dilihat bahwa terdapat tujuh perusahaan yang masuk kedalam portofolio optimal dikarenakan nilai ERB nya lebih besar dari Cid an daftar perusahaan tersebut adalah adalah LPKR, PGAS, PTPP,SMGR, SRIL,UNTR, dan UNVR.

\section{PENUTUP}

\section{Kesimpulan}

Berdasarkan hasil penelitian dan analisis yang telah dilakukan oleh peneliti pada bab IV maka dapat disimpulkan sebagai berikut :

1. Terdapat tujuh saham yang komposisi nya sesuai dengan pembentukan portofolio optimal model indeks tunggal. Ketujuh saham tersebut yaitu : LPKR, PGAS, PTPP,SMGR, SRIL,UNTR, dan UNVR dikatakan optimal di karenakan nilai ERB nya lebih besar dibandingkan nilai $\mathrm{Ci}$.

\section{Keterbatasan Penelitian}

Penelitian ini hanya terbatas pada penentuan portofolio optimal saham-saham perusahaan yang masuk kedalam IDX 30 tanpa ada evaluasi dan efisiensi kinerja saham perusahaan tersebut.

\section{Saran}

1. Bagi Investor

Investor dapat berinvestasi pada ketujuh portofolio optimal saham perusahaan yang masuk dalam IDX 30 tersebut pada periode mendatang karena hal ini terbukti dapat mengurangi risiko.Selain itu investor juga perlu menambah analisis kinerja saham agar diperoleh keputusan invstasi yang lebih baik lagi.

2. Bagi Perusahaan yang Tidak Optimal

Bagi perusahaan yang sahamnya belum memenuhi syarat untuk masuk dalam portofolio optimal, diharapkan dapat melakukan evaluasi kinerja saham. Evaluasi ini bertujuan agar kinerja saham perusahaan lebih baik pada periode yang akan datang. Dan supaya para investor tertarik untuk berinvestasi pada perusaahn tersebut.

3. Bagi Peneliti Selanjutnya

Bagi peneliti selanjutnya sebaiknya menggunakan atau menambah indikator untuk menilai saham,dan menambah periode penelitian. 


\section{DAFTAR PUSTAKA}

Choiriyah, Febri, Nur.2016. Portofolio Optimalisasi Efisiensi Risk dan Return Model Indeks Tunggal pada Perusahaan Building Contraction,jurnal ilmu dan riset manejemen:volume 5, nomor 5, Maret 2016. Diunduh 2 Desember 2017

Dahlan, Suyadi,Topowijoro dan Zahroh Z.A.(2013)Penggunaan Single Index Model dalam Analisis Portofolio untuk Meminimumkan Risiko bagi Investor di Pasar Modal (Studi pada Saham Perusahaan yang Tercatat dalam Indeks LQ 45 di Bursa Efek Indonesia 2010-2012) Jurnal Administrasi Bisnis (JAB)No.2. diunduh 2 Desember 2017.

Firdausy, Ahmad, Denny. 2015. Analisis Investasi Melalui Penetapan Portofolio Optimal Saham LQ 45 Bursa Efek Indonesia.Jurusan Akuntansi, Fakultas Ekonomi, Universitas Jember (UNEJ).Diunduh 13 Desember 2017.

http://www.idx.co.id/.

Samsul, Muhammad.2015. Pasar Modal dan Manajemen Portofolio. Surabaya: Erlangga.

Setiawan, Sandy. 2017. Analisis Portofolio Optimal Saham- Saham LQ 45 Menggunakan Sinle Indeks Model di Bursa Efek Indonesia Periode 2013-2016.Jurnla of Accounting and Business Studies.Vol 1, no 2, Maret 2017.Diunduh 20 Desember 2017.

Sunariyah, S.E.M.Si. 2011. Pengantar Pengetahuan Pasar Modal.Edisi keenam. UPP STIM YKPN. Yogyakarta .

Sulistiyowati,Endang.2017.

Analisis

Portofolio Optimal Model Indeks
Tunggal pada Perusahaan Properti and Real Estate. Jurnal Ilmu dan Riset Manajemen, Volume,6 nomor 5. Diunduh 2017. 
